\title{
Behavioral, hepato-morphological, and biochemical studies on the possible protective effect of black seed and water bath against change-mediated heat stress on pigeon
}

\author{
Ramadan D. EL Shoukary ${ }^{1 *}$, Ramy K. Sayed ${ }^{2}$ and Rasha I. Hassan ${ }^{3}$
}

\begin{abstract}
Background: Heat stress condition $\left(34^{\circ} \mathrm{C}\right.$, Egyptian summer season) in pigeon leads to a lot of negative impacts on behavior, physiology, hepatic architecture, and biochemical parameter changes. The aim of this study was to evaluate the effect of water bath as a managerial and low-quality diet (wheat) as well as some feed additives (propolis or black seed) as nutritional factors for improvement of these changes.

Results: The result showed that heat stress condition induced a significant decrease in feeding behavior, feed intake, body gain, $H \backslash L$ ratio, and total antioxidants, while catalase, glucose, and cholesterol levels were significantly increased. These changes were accompanied by severe damage of the hepatic tissues that illustrated as swelling, vacuolation, collagenous tissue deposition, and venous congestion.

Conclusions: The negative effect of heat stress condition was significantly declined by addition of water bath or feeding on black seed grains. Furthermore, feeding on the wheat grains only during summer season had economic impact as it did not show any more negative effects on the studied parameters. In conclusion, water bath and black seed have a protective role against the heat stress-mediated effects.
\end{abstract}

Keywords: Antioxidant, Catalase, Glucose, Hepatocytes, Propolis, Wheat

\section{Background}

Normal pigeon reared temperature is about $22{ }^{\circ} \mathrm{C}$, and when birds kept at $34{ }^{\circ} \mathrm{C}$ for $8 \mathrm{~h} /$ day, they suffer from heat stress condition (Al-Azraqi, 2008). High ambient temperature in Egypt during the summer season generates a status of stress and evokes a combination of behavioral, biochemical, and physiological changes (Faisal, AbdelFattah, El-Hommosany, Abdel-Gawad, \& Ali, 2008). Among these changes, there are less time of feeding, more time of drinking (Mack, Felver-Gant, Dennis, \& Cheng, 2013), increased agonistic behavior (Bozakova, 2008), decreased feed intake resulting in decreased body weight

\footnotetext{
* Correspondence: Ramadandardeer8@gmail.com

${ }^{1}$ Department of Animal Hygiene, Faculty of Veterinary Medicine, Assiut

University, Assiut 71526, Egypt

Full list of author information is available at the end of the article
}

(Mujahid, Akiba, \& Toyomizu, 2009), decreased feed conversion rate (Felver-Gant, Mack, Dennis, Eicher, \& Cheng, 2012), deleterious effects on hemoglobin (Pawan, Singh, Raina, \& Kumar, 2012), and increase in heterophil: lymphocyte ratio (H/L ratio, Prieto, \& Campo, 2010).

The increase in body temperature also induces a variety of histopathological changes in the lungs, kidney, spleen, placenta, and retina (Ahmed \& Mazher, 2009; Padmanabhan, NM, Ahmed, Kataya, \& Ayoub, 2005; Piyathaisere et al., 2003; Suzuki et al., 2004). The liver is a sentinel organ for heat stress (Agrawal \& Gupta, 2013; Flanagan , Ryan, Gisolfi, \& Moseley, 1995; Hall et al., 2000).

In order to face the negative effects of heat stress and combat these stressful conditions, lowering physiological responses to stress conditions and alarming different forms of environmental enrichment as water baths in layer 
housing were done (Appleby \& Hughes, 1995). Also, reducing heat production of bird to face excessive surrounding heat during heat stress condition by using low-quality diet (wheat) was reported, leading to non-significant reduction in body weight, body weight gain (Laudadio et al., 2012), and feed conversion ratio (Kamraa et al., 2008). Furthermore, black seed was supplemented to overcome the deleterious effects of hot climatic conditions (Tollba \& Hassan, 2003), with a significant increase in feeding behavior, feed intake, body weight, and body gain in heat stress broilers (EL-Shoukary, Madeha, Darwish, \& AbdelRahman, 2014).

This study aimed to investigate the effect managerial factors as water bath and nutritional factors as low-quality diet (wheat) as well as some feed additives (propolis or black seed) on behavior, hepatic architecture, and biochemical parameters of pigeon under heat stress condition.

\section{Methods}

\section{1-birds}

This study was conducted at the Department of Animal Hygiene, Faculty of Veterinary Medicine, Assiut University, Egypt. Thirty-sex pairs of 18-24-month-old parent local Egyptian Baladi pigeons "belong to Rock dove, Columbai livia" were purchased from a pigeon fancier in Assiut Governorate, Egypt, and were distributed according to its consistent mating systems (sex ratio of pigeons 1:1). The male weight is $340 \pm 9 \mathrm{~g}$, while the female weight is about $320 \pm 6 \mathrm{~g}$.

\section{Management}

\section{Temperature, humidity, and lighting}

Pigeons were maintained indoors (Spudeit et al., 2013) under natural day light (12-h light, 12-h dark diurnal cycle) and exposed to surrounding environmental temperature.

Temperature degree and humidity percentage were recorded twice daily throughout the experiment period using a wall mount wet and dry bulb hygrometer and wall mount thermometer. The average temperature and relative humidity during experimental period (4 months) were $34: 36{ }^{\circ} \mathrm{C}$ and $61: 64 \%$, respectively.

\section{Feeders, waters, and water bath}

Plastic containers were used as feeders and drinkers (Moreki, 2006). Drinker containers were easily cleaned because it may use as a water bath by birds. Feed and water were provided to the birds ad libitum. Each bird had $10 \mathrm{~cm}$ of feeder; this allowed the birds to feed simultaneously, facilitated natural behavior and reduced aggression. Water bath was provided only in case of water bath group (as managerial factor).

\section{Space requirement}

Two pairs were put in partition $100 \times 100 \times 250 \mathrm{~cm}$ high (Gwenith, 1986).

\section{Cleaning and disinfection}

Disinfection was carried out by using Biocid-30 (Luyckx et al., 2017), following the procedure outlined by manufacturer. It is a product of Pfizer Animal Health disinfectant (iodine-stabilized) and detergent used for rearing livestock and poultry equipment. It is used for cleaning and disinfection of equipment and materials to prevent spreading of disease.

\section{Bird identifications and medication}

Bird identifications were carried out by leg band, which was changed if any changes occur in it. On the other hand, vitamins, minerals, and antibiotics were used in the first days after bird arrival and also during formation of the parent pairs.

\section{Experimental diets}

Composition and chemical analysis of the experimental diets were illustrated in additional Table 1.

\section{Experimental design}

Thirty-six pairs of adult pigeon were divided into six groups, and each group contained six pairs (two pairs $x$ three replicates) as follows:

1. Control group: reared under normal temperature $\left(22: 24{ }^{\circ} \mathrm{C}\right)$ and fed basal diet.

2. Heat-stressed group: reared under heat stress condition (summer, $34: 36{ }^{\circ} \mathrm{C}$ ) and fed basal diet.

3. Water bath group (as managerial effect): reared under heat stress condition $\left(34: 36{ }^{\circ} \mathrm{C}\right)$, and fed basal diet plus presence of water bath.

4. Low-quality diet group (wheat as nutritional effect): reared under heat stress condition $\left(34: 36^{\circ} \mathrm{C}\right)$ and fed wheat diet.

5. Feed additives group I (black seed group): reared under heat stress condition $\left(34: 36^{\circ} \mathrm{C}\right)$ and fed basal diet containing $2 \%$ black seed.

6. Feed additives group II (propolis group): reared under heat stress condition $\left(34: 36^{\circ} \mathrm{C}\right)$ and fed basal diet containing $500 \mathrm{mg}$ of propolis.

\section{Experimental procedures}

Experimental period of this study was about 4 months and divided as follows:

1. Pre-experimental period: It lasted for 30 days of spring season from 23 April 2017 till 22 May 2017 and was divided into two parts; 10 days for adaptation of the birds to the lab conditions and 
Table 1 Composition and chemical analysis of the experimental diets

\begin{tabular}{|c|c|c|c|c|}
\hline \multirow[t]{2}{*}{ Item } & \multicolumn{4}{|c|}{ Experimental diets } \\
\hline & Basal diet & Wheat diet & Propolis diet & Black seed diet \\
\hline \multicolumn{5}{|l|}{ Ingredients (\%) } \\
\hline Yellow corn & 71.00 & 76.00 & 71.00 & 67.00 \\
\hline Soybean meal & 19.50 & 11.84 & 19.50 & 20.30 \\
\hline Wheat bran & - & 6.5 & - & - \\
\hline Sunflower oil & 4.00 & - & 4.00 & 5.20 \\
\hline Black seed & - & - & - & 2.00 \\
\hline Propolis & - & - & 0.05 & - \\
\hline Limestone & 3.40 & 3.40 & 3.35 & 3.40 \\
\hline Sodium phosphate dibasic & 1.45 & 1.45 & 1.45 & 1.45 \\
\hline Lysine & - & 0.14 & - & - \\
\hline Methionine & 0.05 & 0.07 & 0.05 & 0.05 \\
\hline Common salt & 0.30 & 0.30 & 0.30 & 0.30 \\
\hline Premix* & 0.30 & 0.30 & 0.30 & 0.30 \\
\hline Total & 100.00 & 100.00 & 100.00 & 10.00 \\
\hline \multicolumn{5}{|l|}{ Calculated values } \\
\hline $\mathrm{ME}, \mathrm{kcal} / \mathrm{kg}$ & 3199.71 & 2810.03 & 3199.71 & 3199.46 \\
\hline Crude protein, $\%$ & 15.52 & 12.55 & 15.52 & 15.50 \\
\hline Calcium, \% & 1.33. & 1.33 & 1.33. & 1.33 \\
\hline Available phosphorus,\% & 0.40 & 0.40 & 0.40 & 0.40 \\
\hline Lysine, \% & 0.71 & 0.71 & 0.71 & 0.72 \\
\hline Methionine, \% & 0.30 & 0.03 & 0.30 & 0.30 \\
\hline
\end{tabular}

ME mean metabolized energy

*Mineral and vitamin premix Heromix broilers (Heropharma Co., Egypt). Each 2.5 kg contain vit. A, 1,200,000 IU; vit. D3, 300,000 IU; vit. E, 700 mg; vit. k3, 500 mg; vit. B1, 500 mg; vit. B2, 200 mg; vit. B6, 600 mg; vit. B12, 3 mg; vit. C, 450 mg; niacin, 3000 mg; methionine, 3000 mg; pantothenic acid, 670 mg; folic acid 300 mg; biotin, 6 mg; choline chloride, 10,000 mg; magnesium sulphate, 3000 mg; copper sulphate, 3000 mg; iron sulphate, 10,000 mg; zinc sulphate, 1800 mg; cobalt sulphate, $300 \mathrm{mg}$

also for pair formation, and 20 days to ensure pigeon production and reproduction ability and normal behavior in the experimental lab conditions according to (Spudeit et al., 2013).

2. Experimental period: It lasted for 90 days from 23 May 2017 till 22 August 2017 which was equal to summer season days $\left(34: 36{ }^{\circ} \mathrm{C}\right)$

\section{Measured parameters}

\section{Behavioral parameters}

\section{Behavioral observations and technique}

Behavioral observation was started after 1 month from introducing pigeons into the experimental room to become more adaptive to the presence of the camera used for behavior recording.

Continuous observation techniques according to Murton, Thearle, and Lofts (1969) were used to record the frequency of certain behaviors during 2-min intervals for a total of $30 \mathrm{~min}$ daily for each treatment replicate. Observations were carried out all over a day, starting from 7 am till $6 \mathrm{pm}$ for three unsuccessive days $\backslash$ week. So, each day about $11 \mathrm{~h}$, four periods for each hour except morning time five periods $(4 \times 11=44+1=45 \times 2 \mathrm{~min}=$ $90 \min \backslash 3=30 \min =15$ period $)$ according to Fabricius and Jansson (1963) who stated that observation were made over a period of days rather than in one long initial period since the behavior would be expected to change both quantitatively and qualitatively over time.

\section{Behavioral catalog or unit's definition (ethogram)}

The behavioral ethogram was described in Table 2 .

\section{Productive performance of pigeons}

The following criteria weekly measured for each replicate:

1. Live body weight (LBW): Live body weight of each replicate (contains two pairs of adult pigeon with its squabs) was recorded at the beginning of experiment and then weekly. It was measured in constant morning time (7 am) before offering feed and water. 
Table 2 Behavioral ethogram

\begin{tabular}{|c|c|}
\hline Behavior & Definition \\
\hline Ingestive behavior & $\begin{array}{l}\text { According to Spudeit et al. (Spudeit } \\
\text { et al. 2013) }\end{array}$ \\
\hline (a) Feeding & Pigeon's head located inside the feeder. \\
\hline (b) Drinking & Pigeon's head in contact with drinker \\
\hline Comfort behavior & According to Spiteri (1975) \\
\hline $\begin{array}{l}\text { (a) Foot and ground } \\
\text { pecking }\end{array}$ & The pigeon pecks at its foot or the ground \\
\hline (b) Wing and leg stretch & $\begin{array}{l}\text { Stretches its leg or wing upward and } \\
\text { downward. }\end{array}$ \\
\hline (c) Preening & $\begin{array}{l}\text { Gentle pecking or scratching its own } \\
\text { feathers. }\end{array}$ \\
\hline Aggressive behavior & According to Spiteri (1975) \\
\hline (a) Wing flick & $\begin{array}{l}\text { Pigeon fans out its tail, raises the wing } \\
\text { backwards }\end{array}$ \\
\hline (b) Wing fend & The wing is brought sharply outwards. \\
\hline (c) Fluffing & Bird fluffed its feather. \\
\hline
\end{tabular}

2. Body weight gain (BWG): Body weight gains of each replicate (contain two pairs of adult with its squabs) were recorded weekly which calculated by subtracting the LBW at the beginning of each week from the end of the same week (Abou Khashaba, Mariey, \& Ibrahem, 2009).

3. Feed intake (FI): The amount of feed intake was weekly recorded in each replicate by the sum of the measured weights of the food offered to the birds each day (Dagaas \& Claveria, 2008).

4. Feed conversion ratio (FCR): Calculated weekly as kilogram feed intake/kilogram gain of body weight.

\section{Blood parameters}

Blood parameters were estimated in the laboratory of Hygiene Department at the Faculty of Veterinary Medicine, Assuit University, Egypt. Blood samples were collected, and different parameters were estimated according to Al-Gamal (2014).

At the end of the experiment, all birds were weighted and slaughtered according to Islamic or halal method and the blood samples were collected from each bird during the bird's exsanguinations in two test tubes. About $2 \mathrm{~cm}^{3}$ of blood from each bird was collected in heparinized test tube to determine the hematological parameters of blood ( $\mathrm{Hb} \%$; WBCS count and differential leucocytic count); $3 \mathrm{~cm}^{3}$ of blood from each bird was collected in test tube without anticoagulant to determine the chemical blood parameters.

The tubes were kept at the room temperature for $30 \mathrm{~min}$, stored at a refrigerator for 60-90 $\mathrm{min}$, and then centrifuged at 3000 r.p.m. for $10 \mathrm{~min}$, followed by transferring of the serum after separation to another Epindoorf's tube using micropipette. The sera were kept at $-20{ }^{\circ} \mathrm{C}$ until analysis using commercial kit according to the procedure outlined by the manufacturer.

\section{Chemical parameters}

The stored sera were used for chemical analysis estimation using commercial test kits by Digital-VIS/ultraviolet spectrophotometer. The chemical analysis estimated during this study included the following:

1. Catalase activity was determined by the method of Caliborne (1985).

2. Total antioxidant capacity (TAC).

3. Glucose and cholesterol level.

\section{Blood hematological parameters}

The heparinized blood test tube was used to determine the following:

1. Blood hemoglobin (Hb\%): $\mathrm{Hb} \%$ was determined by using Sahli apparatus according to Beutler (1984).

2. Total leucocytes count (TLC OR WBCS count): Only 24 non-coagulated blood samples (12 males + 12 females) were used for WBCS count according to Natt and Herrick (1952).

3. Differential count of white blood cells: according to Schalm, Jain, and Caroll (1975). Six blood smears (three females + three males) from each group were prepared and stained using Giemsa stain. A total of 100 white cells were counted and heterophil/ lymphocyte ratios were calculated.

4. Heterohil/lymphocyte $(\mathrm{H} / \mathrm{L})$ ratio: $\mathrm{H} / \mathrm{L}$ ratios were calculated using the following equation: $\mathrm{H} / \mathrm{L}$ ratio $=$ the number of heterophil cells $\mid$ the number of lymphocyte cells.

\section{Gross anatomical examination of the liver}

After complete bleeding, an incision was made on the ventral wall caudocranially from the vent to the shoulder joint, extending laterally on both sides of the keel bone to get access for the viscera. The anatomical features of the liver and its relations were described. The liver was then dissected, and its absolute weight and relative weight to the total body weight were measured.

\section{Tissue preparation and histological examination}

The livers of the birds were dissected and kept after rapid washing with distilled water in $10 \%$ neutral buffered formalin for $24 \mathrm{~h}$. Proper fixed samples were extensively washed in ethanol $70 \%(3 \times 24 \mathrm{~h})$ to remove fixative, and then, the specimens were dehydrated in ascending graded concentrations of ethanol (80, 95, and $100 \%$ ), cleared in xylene, and embedded in paraffin wax. Sections of $4 \mu \mathrm{m}$ thick were cut by using microtome, dewaxed in xylene $(2 \times 30 \mathrm{~min})$, rehydrated in a descending series of ethanol $(100,95,80$, and 
70\%), and washed by distilled water. The sections were stained with hematoxylin and eosin (H\&E) stain (Harris, 1900) for general histological examination, where the hematoxylin component stains the nuclei blue or black, while the eosin stains cell cytoplasm and most connective tissue fibers in varying shades and intensities of pink. Moreover, crossmon's trichrome stain (Crossmon, 1937) was performed for differentiation of collagenous connective tissue fibers which stained green. All stain techniques were done as described by Bancroft, Layton, and Suvarna (2013). After staining, the sections were dehydrated again in an ascending series of ethanol $(70,95$, and 100\%), cleared in xylene $(2 \times$ $10 \mathrm{~min}$ ), and mounted with DPX. The sections were examined by Leitz Dialux 20 Microscope. The photos were taken using a Canon digital camera (Canon Power shot A 95).

\section{Statistical analysis}

The data was analyzed by one way ANOVA procedure using the statistical computer Program SPSS 13.00 Software (SPSS Inc., Chicago, IL, USA) to compare between means, and significance was considered when $P<.05$. Means were compared by Duncan's test when a significant difference was detected.

\section{Results}

Effect of heat stress on behavior, performance, and biochemical parameters

Exposure of the pigeon to the heat stress condition leading to significant increase in drinking behavior, food conversion ratio, $H \backslash R$ ratio, catalase, glucose, and cholesterol levels. In contrast, significant decrease in feeding behavior, feed intake, body gain of parent pigeon only, and total antioxidant capacity were detected (Tables 3, 4 and 5).

\section{Nutritional effect on behavior, performance, and} biochemical parameters on heat-stressed pigeon Nutritional effects as shown in Tables 3, 4 and 5 demonstrated that feeding of pigeon on wheat diet during heat stress condition induced significant decrease in feeding/drinking ratio, aggressive behavior, and weight gain, with significant increase of catalase, glucose, and cholesterol levels.

Addition of black seed in pigeon diet during heat stress condition clarified a significant increase in feeding behavior, ground pecking, feed intake, body gain, and total antioxidant capacity, concomitant with significant decrease in aggressive behavior, food conversion ratio, glucose, cholesterol, and catalase levels.

Propolis leading to significant increase in total antioxidant capacity, while significant decreases in feed intake, feed conversion ratio, catalase, glucose, and cholesterol levels was found.

\section{Managerial effect on behavior, performance, and biochemical parameters on heat-stressed pigeon}

Pigeon reared in the presence of water bath during heat stress condition showed higher feeding and comfort behavior, feed intake, body gain, and total antioxidant level. Moreover, significant decrease in drinking, aggressive behavior, $\mathrm{H} \backslash \mathrm{R}$ ratio, catalase, glucose, and cholesterol level were detected (Tables 3, 4 and 5).

\section{Liver gross variables}

The liver of the examined pigeon consists of large right and small left lobes, which are separated cranially and caudally by a shallow and a deep fissure, respectively. The largest part of the liver is enclosed by the ribs where the parietal surface of the liver is convex and directed ventrally, related to the wall of the body cavity, while the visceral surface is concave and directed dorsally, related to the heart, proventriculus, gizzard, the cranial end of the duodenum, and the spleen. The liver has a depression, transverse fossa that corresponds to the hepatic porta of the mammals. Both gall bladder and intermediate process are absent in the pigeon's liver.

Table 3 Managerial and nutritional effect on ingestive, comfort, and aggressive behavior of heat-stressed pigeon

\begin{tabular}{|c|c|c|c|c|c|c|}
\hline Group item & Control & Heat stress & Water bath & Propolis & Black seed & Wheat diet \\
\hline \multicolumn{7}{|c|}{ Ingestive behavior (act\30 min) } \\
\hline Feeding behavior & $10 \pm 0.8^{\mathrm{a}}$ & $6.7 \pm 1.6^{b}$ & $9.7 \pm 0.9^{\mathrm{a}}$ & $6.9 \pm 0.6^{b}$ & $10 \pm 2.3^{\mathrm{a}}$ & $6.6 \pm 0.6^{b}$ \\
\hline Drinking behavior & $2.9 \pm 0.6^{b}$ & $4.7 \pm 0.9^{a}$ & $2.1 \pm 0.6^{b}$ & $4.4 \pm 0.7^{a}$ & $4.1 \pm 0.1^{a}$ & $3.4 \pm 0.5^{\mathrm{a}}$ \\
\hline Feeding/drinking ratio & $3.7 \pm 0.9^{\mathrm{a}}$ & $3.8 \pm 0.9^{\mathrm{a}}$ & $4.3 \pm 0.9^{a, b}$ & $1.6 \pm 0.7^{a, b}$ & $2.9 \pm 0.7^{a, b}$ & $2.3 \pm 0.9^{b}$ \\
\hline \multicolumn{7}{|c|}{ Comfort behavior (act\30 min) } \\
\hline Preening & $12.3 \pm 0.6^{b}$ & $13.3 \pm 0.8^{b}$ & $19.7 \pm 4.9^{a}$ & $9.4 \pm 0.9^{b}$ & $10.7 \pm 1.6^{b}$ & $9.7 \pm 1.6^{\mathrm{b}}$ \\
\hline Wing and leg stretching & $1.9 \pm 2.5^{b}$ & $2.1 \pm 2.5^{b}$ & $3.1 \pm 1.2^{\mathrm{a}}$ & $2.9 \pm 2.5^{\mathrm{a}, \mathrm{b}}$ & $2 \pm 0.4^{b}$ & $1.7 \pm 0.3^{b}$ \\
\hline Foot and ground pecking & $4.7 \pm 0.9^{b}$ & $4.7 \pm 1.6^{b}$ & $8.8 \pm 1.9^{a}$ & $5.7 \pm 1.6^{\mathrm{b}}$ & $5.9 \pm 0.3^{b}$ & $8.2 \pm 1.6^{a}$ \\
\hline \multicolumn{7}{|c|}{ Aggressive behavior (wing flick, wing fend, and fluffing) (act \30 min) } \\
\hline Aggressive behavior & $10.7 \pm 1.4^{\mathrm{a}}$ & $11.7 \pm 1.4^{\mathrm{a}}$ & $8.8 \pm 1.3^{b}$ & $9.2 \pm 1.4^{a, b}$ & $8.3 \pm 0.6^{b}$ & $7.5 \pm 1.2^{\mathrm{b}}$ \\
\hline
\end{tabular}

Means with different superscripts in the same row differ significantly 
Table 4 Managerial and nutritional effect on performance parameter of two pairs of parent with or without squabs of heat stressed pigeon

\begin{tabular}{|c|c|c|c|c|c|c|}
\hline Group item & Control & Heat stress & Water bath & Propolis & Black seed & Wheat diet \\
\hline \multicolumn{7}{|c|}{ Performance parameter of two pairs with squabs } \\
\hline Feeding intake (kg) & $0.77 \pm 0.05^{a}$ & $0.39 \pm 0.02^{b}$ & $0.54 \pm 0.043^{\mathrm{a}}$ & $0.27 \pm 0.04^{c}$ & $0.74 \pm 0.02^{\mathrm{a}}$ & $0.45 \pm 0.04^{b}$ \\
\hline Body weight $(\mathrm{kg})$ & $1.61 \pm 0.03^{a}$ & $1.41 \pm 0.02^{b}$ & $1.49 \pm 0.054^{\mathrm{a}, \mathrm{b}}$ & $1.43 \pm 0.2^{\mathrm{a}, \mathrm{b}}$ & $1.52 \pm 0.03^{\mathrm{a}}$ & $1.37 \pm 0.013^{b}$ \\
\hline Body gain $(\mathrm{kg})$ & $0.20 \pm 0.08^{\mathrm{a}}$ & $0.03 \pm 0.01^{b}$ & $0.13 \pm 0.02^{\mathrm{a}}$ & $0.06 \pm 0.01^{b}$ & $0.17 \pm 0.02^{\mathrm{a}}$ & $0.01 \pm 0.01^{c}$ \\
\hline Food conversion ratio & $3.9 \pm 0.9^{c}$ & $20.7 \pm 4.91^{\mathrm{a}}$ & $20.7 \pm 6.29^{a}$ & $16.6 \pm 0.01^{b}$ & $17.9 \pm 1.9^{\mathrm{b}}$ & $27.2 \pm 4.91^{\mathrm{a}}$ \\
\hline \multicolumn{7}{|c|}{ Performance parameter of two pairs of parent only } \\
\hline Body weight $(\mathrm{kg})$ & $1.42 \pm 0.03^{\mathrm{a}, \mathrm{b}}$ & $1.38 \pm 0.015^{b}$ & $1.38 \pm 0.01^{b}$ & $1.39 \pm 0.2^{\mathrm{a}, \mathrm{b}}$ & $1.35 \pm 0.03^{b}$ & $1.34 \pm 0.01^{b}$ \\
\hline Body gain $(\mathrm{kg})$ & $0.05 \pm 0.02^{\mathrm{a}}$ & $0.03 \pm 0.01^{b}$ & $0.03 \pm 0.02^{b}$ & $0.04 \pm 0.01^{a, b}$ & $0.03 \pm 0.02^{b}$ & $0.01 \pm 0.01^{c}$ \\
\hline
\end{tabular}

Means with different superscripts in the same row differ significantly

In this study, the total body weight, absolute weight, and relative weight of the liver were significantly decreased during heat stress and also in the group with the low diet $(p<.05)$. These decreases were significantly recovered with the managerial factor as water bath and also with the nutritional factors as black seed and propolis (Fig. 1).

\section{Histological finding}

The histological examination of the liver tissue in the control group showed normal liver architecture (Fig. 2a, b). The liver lobules consisted of anastomosing cords of hepatocytes radiating from the thin-walled central vein. The hepatocytes were acidophilic with central nuclei. The hepatic cords were alternated with narrow irregular blood spaces, the hepatic sinusoids. The portal area that located in the corners of the hepatic lobules contained branches from the hepatic artery, portal vein, and bile duct.

Examination of the liver in the heat stress group revealed distorted hepatic cords, enlarged hepatocytes with severe vacuolation, dilatation and congestion of the central veins, dilated and disrupted blood sinusoids, and increased collagenous fiber deposition (Fig. 2c, d). Moreover, disruption of the hepatic cords with inflammatory cell infiltrations were observed in the heat stress group fed on wheat diet (Fig. 3a, b).

The presence of the water bath as a managerial factor (Fig. 3c, d), and feeding on the black seed as a nutritional factor (Fig. 4a, b) under the heat stress condition demonstrated a protective effect and minimized the damage effect of the heat stress on the liver tissue. The hepatic sinusoids preserved a normal size, with less collagenous fiber's deposition. The hepatic cords maintained their architecture, and the inflammatory cell infiltrations were absent. However, less degree of hepatocytes' vacuolation and veins' congestion was observed. Feeding on propolis during heat stress condition reported no protective effect on the hepatic tissues under heat stress condition (Fig. 4c, d).

\section{Discussion}

Heat stress condition is associated by less time of feeding, more time of drinking, increased agonistic behavior,

Table 5 Managerial and nutritional effect on blood parameters of heat-stressed pigeon

\begin{tabular}{|c|c|c|c|c|c|c|}
\hline Group item & Control & Heat stress & Water bath & Propolis & Black seed & Wheat diet \\
\hline \multicolumn{7}{|c|}{ Hematological blood parameters } \\
\hline T.L.C & $13.3 \pm 0.9$ & $13.6 \pm 1.7$ & $13.7 \pm 1.3$ & $13 \pm 1.1$ & $12.9 \pm 0.8$ & $12.8 \pm 1.1$ \\
\hline H.B & $15.7 \pm 0.2$ & $17 \pm 0.69$ & $15.3 \pm 0.49$ & $15 \pm 0.8$ & $14.6 \pm 0.6$ & $14.9 \pm 0.01$ \\
\hline Neutrophils \% & $35.5 \pm 1.45$ & $37 \pm 1.45$ & $40.5 \pm 2.84$ & $37 \pm 3.45$ & $38.4 \pm 2.2$ & $34.5 \pm 7.22$ \\
\hline Lymphocyte \% & $40.3 \pm 1.21$ & $50 \pm 1.21$ & $43.5 \pm 10.07$ & $50 \pm 1.21$ & $45.5 \pm 1.3$ & $50 \pm 7.51$ \\
\hline Monocytes \% & $21.5 \pm 0.58^{\mathrm{a}}$ & $8.5 \pm 0.58^{b}$ & $13 \pm 0.29^{a, b}$ & $11.5 \pm 0.58^{b}$ & $14.5 \pm 0.6^{a, b}$ & $11.5 \pm 0.012^{\mathrm{a}, \mathrm{b}}$ \\
\hline Heterophils \% & $2.7 \pm 0.58^{b}$ & $4.5 \pm 0.58^{\mathrm{a}}$ & $3 \pm 0.58^{b}$ & $3.5 \pm 0.58^{\mathrm{a}, \mathrm{b}}$ & $2.6 \pm 0.5^{b}$ & $4 \pm 0.29^{a}$ \\
\hline H:L ratio & $0.06 \pm 0.04^{b}$ & $0.09 \pm 0.01^{a}$ & $0.06 \pm 0.009^{b}$ & $0.07 \pm 0.0^{a, b}$ & $0.05 \pm 0.03^{b}$ & $0.08 \pm 0.008^{a, b}$ \\
\hline \multicolumn{7}{|c|}{ Chemicals blood parameters } \\
\hline Catalase & $28.4 \pm 0.88^{\mathrm{a}}$ & $32.4 \pm 2.68^{\mathrm{a}}$ & $11.5 \pm 4.03^{b}$ & $16.5 \pm 4.3^{b}$ & $14.9 \pm 3.03^{b}$ & $30.3 \pm 2.9^{a, b}$ \\
\hline Total antioxidant & $0.22 \pm 0.01^{a}$ & $0.12 \pm 0.01^{b}$ & $0.25 \pm 0.02^{\mathrm{a}}$ & $0.19 \pm 0.003^{\mathrm{a}}$ & $0.23 \pm 0.01^{a}$ & $0.11 \pm 0.02^{b}$ \\
\hline Glucose (mg/dl) & $414 \pm 11.3^{b}$ & $516.9 \pm 6.3^{\mathrm{a}}$ & $397.6 \pm 18.1^{b}$ & $386.4 \pm 14.1^{b}$ & $395.3 \pm 26.3^{b}$ & $590.6 \pm 18.8^{a}$ \\
\hline Cholesterol (mg/dl) & $222 \pm 5.9^{b}$ & $296.3 \pm 15.4^{a}$ & $216.7 \pm 11.9^{b}$ & $234 \pm 4.45^{b}$ & $217.1 \pm 9.2^{b}$ & $285.1 \pm 4.1^{a, b}$ \\
\hline
\end{tabular}

Means with different superscripts in the same row differ significantly 


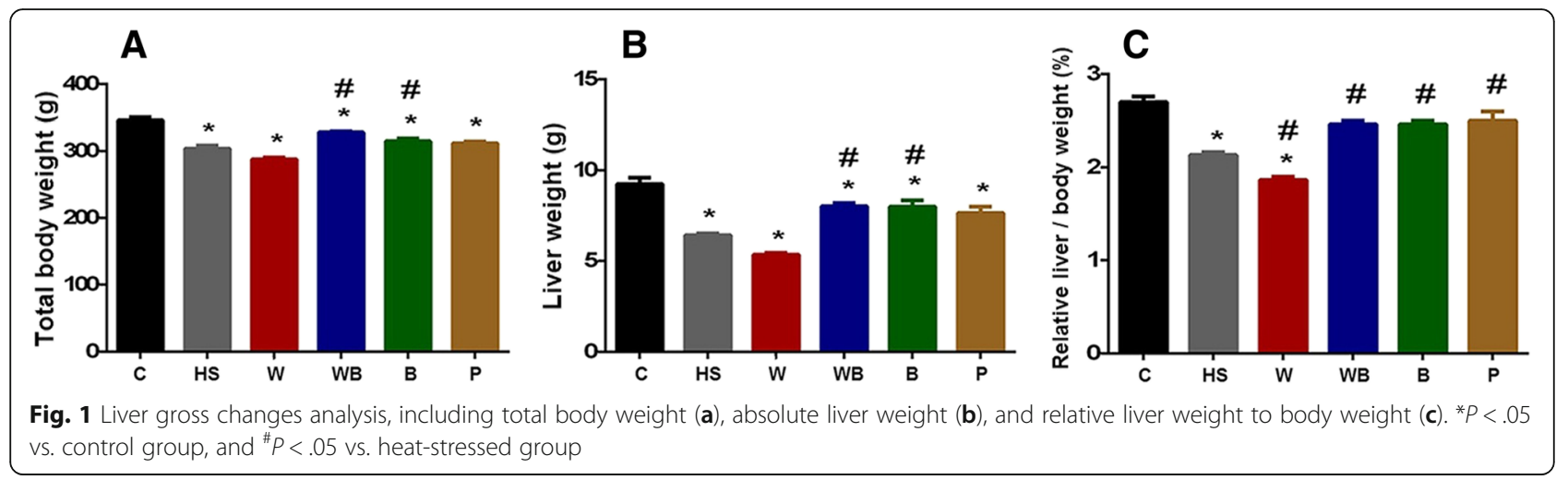

decreased feed intake, and increase in $\mathrm{H} \backslash \mathrm{R}$ ratio (Bozakova, 2008; Mujahid et al., 2009; Prieto \& Campo, 2010; Soleimani, Kasim, Alimon, \& Zulkifli, 2008); these alterations were confirmed in the current study, where there were a decline of body weight, absolute weight, and relative liver weight during both heat stress condition and feeding on low diet. Meanwhile, the previous mentioned weight decline was reversed with the managerial and nutritional factors, compatible with the feeding and drinking behaviors of the birds. Measurement of the body weight has an essential role in evaluation of the health status during treatment period (Dollah, Parhizkar, Abdul, \& Bin Hassan, 2013).

Heat stress condition is followed by the release of catecholamines from the adrenal medulla (Gregory, 1998) as a result of accelerated heart rate (Ewing, Lay Jr, \& Borell, 1999), with stimulation of the parabrachial nucleus causing respiratory rate increase (Gregory, 1998), and packed cell volume and hemoglobin concentration decrease (Furlan, Macari, Moraes, Malheiros, \& Secato, 1999), resulting in hypoxia; this oxygen deficiency is one of the most striking causes of tissue injury (Aengwanich \& Simaraks, 2004). In this regard, examination of the liver in the heat stress group revealed disrupted hepatic cords, swollen and vacuolated hepatocytes, dilated and congested central veins, and increased collagenous fibers infiltrations (Yadav, Yadav, Aryal, \& Bhattacharya, 2012). The increase of hepatic glucose release, as well as fall of the hepatic venous oxygen content is caused by hepato-splanchnic vasoconstriction induced by heat stress conditions (Rowell, Brengelmann, Blackmon, Twiss, \& Kusumi, 1968). These factors probably lead
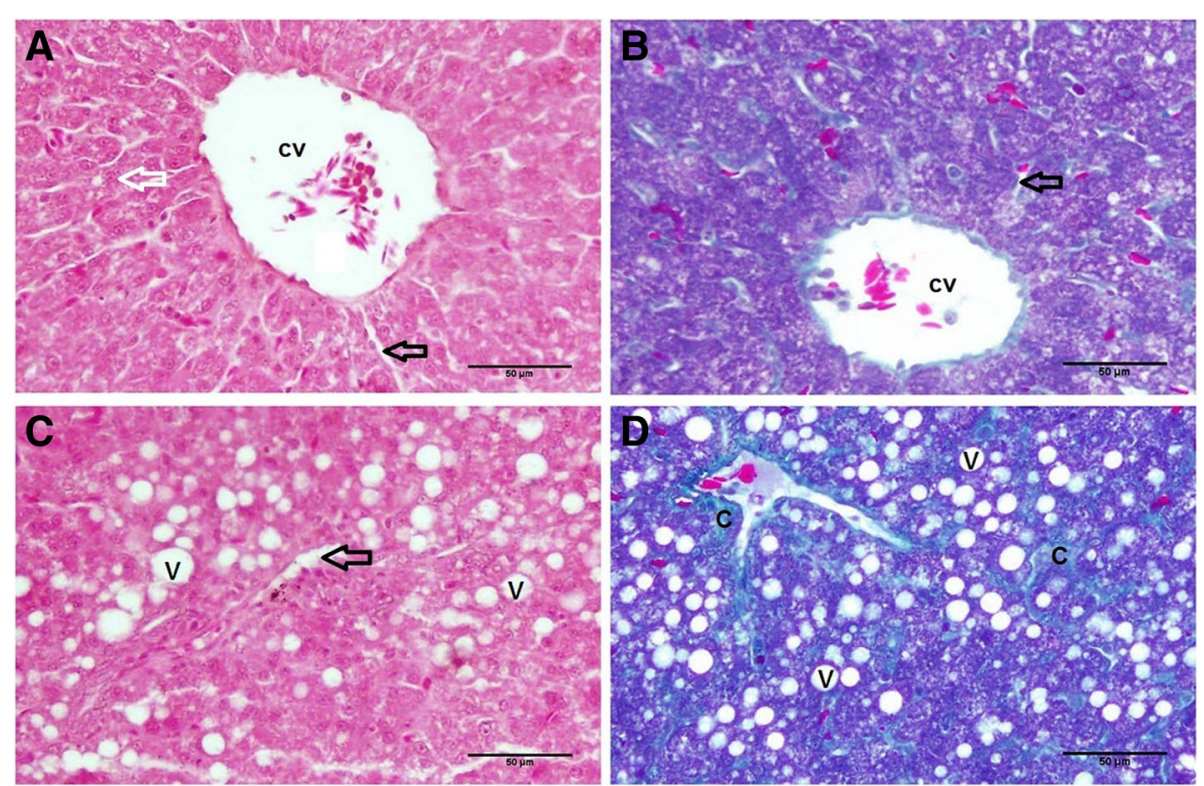

Fig. 2 Photomicrographs of hepatic tissue of control group stained with H\&E stain (a) and crossmon trichrome stain (b) showing the arrangement of hepatocytes (white arrow) on the hepatic cords that radiates from the central vein (Cv), with hepatic sinusoids in between the cords (black arrow). c, d Photomicrographs of the heat-stressed liver stained with H\&E stain (c) and crossmon trichrome stain (d) revealing damage of the hepatic tissue with severe hepatocyte vacuolation (V), swollen hepatic sinusoids (black arrow), and collagenous fiber depositions (C) bar $=50 \mu \mathrm{m}$ 

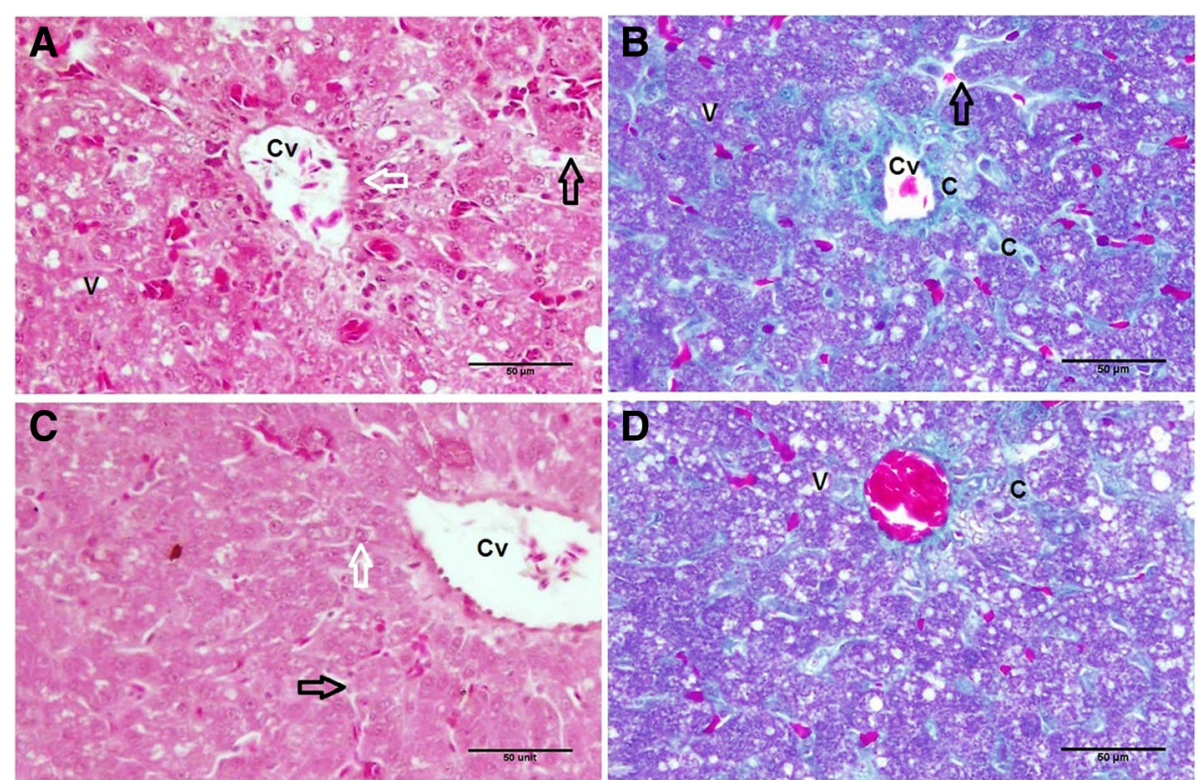

Fig. 3 Hepatic tissue photomicrograph of the wheat diet group stained with H\&E stain (a) and crossmon trichrome stain (b) illustrating the presence of vacuolated hepatocytes ( $V$, swollen hepatic sinusoids (black arrow), with some inflammatory cell infiltrations (white arrow) and collagen fiber depositions (C) around central vein (Cv) and hepatic sinusoids. c, d Photomicrographs of the liver tissue stained with H\&E stain (c) and crossmon trichrome stain (d) clarifying the protective effect of water bath presence under heat stress condition. Note the normal hepatocytes (white arrow) in cords, small-sized sinusoids (black arrow), and thin-walled central vein (Cv); however, degree of hepatocytes vacuolation ( $V$ ) and collagen deposition (C) were found, $\mathrm{bar}=50 \mu \mathrm{m}$
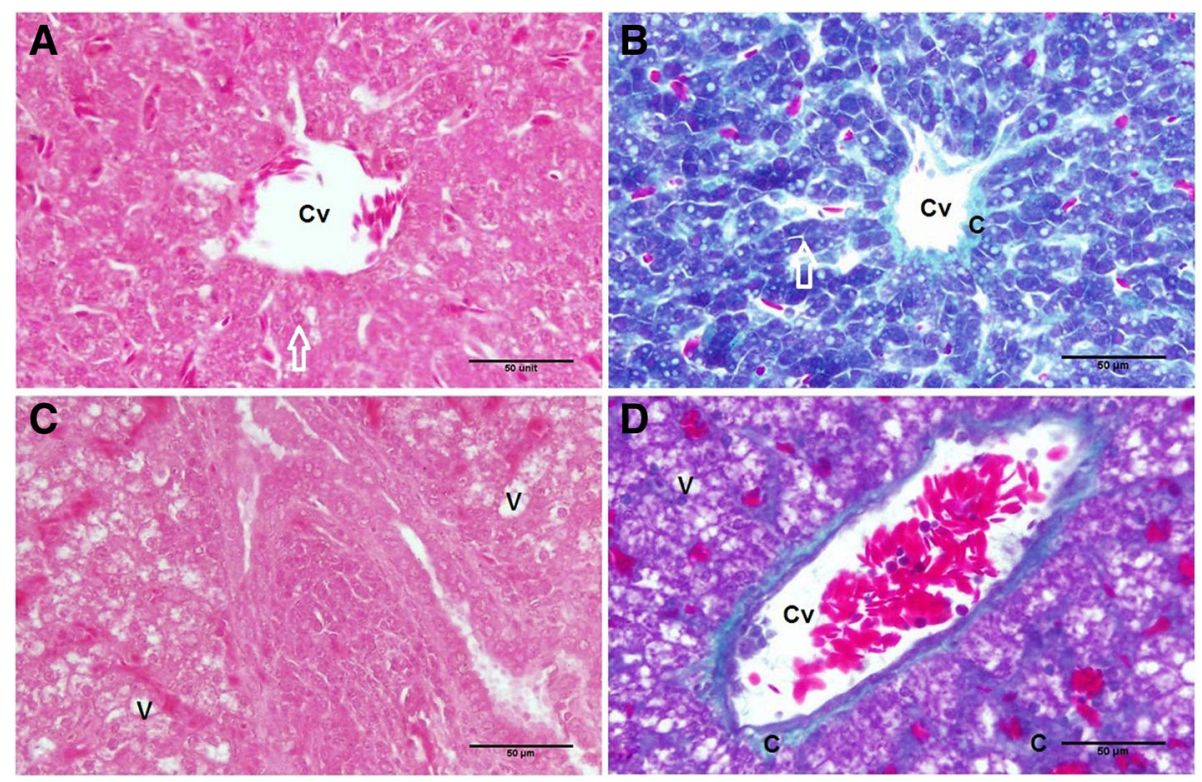

Fig. 4 Photomicrographs of hepatic tissue of black seed group stained with H\&E stain (a) and crossmon trichrome stain (b) demonstrating the protective effect of black seed grains against hepatic damage induced by heat stress. The hepatic architecture in normal with hepatocytes arranged in hepatic cods (white arrow) around the central vein (Cv), which surrounded by less collagenous fibers (C). Very small vacuolated hepatocytes were found. $\mathbf{c}$, $\mathbf{d}$ Photomicrographs of the propolis fed group stained with H\&E stain (c) and crossmon trichrome stain (d) showing the presence of the heat-stressed-mediated damage with no protective effect on the hepatic tissue. Note severe hepatocytes vacuolation ( $V$ ), swollen and congested central vein (Cv), and collagenous fiber depositions (C), bar $=50 \mu \mathrm{m}$ 
to hepato-splanchnic hypoxia and causing hepatocellular damage that were confirmed in this study.

Water bath presence mediated a significant increase in feeding behavior (Cornetto \& Estevez, 2002), comfort behavior, and feed intake. As well, water bath stimulated significant decrease in aggressive behavior (Cornetto \& Estevez, 2001, 2002; Pavlik, Jezova, Zapletal, Bakos, \& Jelinek, 2008), catalase, glucose and cholesterol levels, and $H \backslash R$ ratio, in disagreement with findings of Yang, Tan, Fu, Feng, and Zhang (2010) and Altan, Şeremet, and Bayraktar (2013). Furthermore, hepatic tissue in the presence of water bath demonstrated minimized damage, preserved hepatic sinusoids, and maintained hepatic cords, with less collagenous fiber's deposition. This effect of water bath availability may be due to environmental enrichment that induce normal behavior expression, stress alleviation (Ohara, Oyakawa, Yu, Ninomiya, \& Shusuke, 2015), and physical and psychological wellbeing through reducing aggression and decreasing injury (Cornetto \& Estevez, 2001; Cornetto \& Estevez, 2002). All these positive effects explain the role of water bath in alleviation of heat stress-induced negative effects.

Feeding of the pigeons on low wheat diet under heat stress condition revealed significant decrease in body weight and body weight gain (Kamraa et al., 2008; Laudadio et al., 2012). This may be due to the $14 \%$ crude protein-containing diet that was suggested to be suitable requirement and had no adverse effects on productive and reproductive performance of local baladi pigeons (Abou Khashaba, Mariey, Sayed, \& Elgabry, 2008).

The significant decreases in total antioxidant in case of feeding on wheat diet was agreed with observation of $\mathrm{Te}$ Braake et al. (2008), where the organism's antioxidant machinery can be influenced by protein intake and confirmed the dependence of some antioxidant synthesis on amino acid availability. Moreover, disruption of the hepatic cords with inflammatory cell infiltrations was illustrated.

Feeding of the pigeons on black seed clarified significant increase in feeding behavior and feed intake, with a significant decrease in aggressive behavior and food conversion ratio (Durrani et al., 2007; Gilani, Jabeen, \& Khan, 2004). These results may be due to the nature of black seed as feed additive that stimulate digestive system activity, improve diet palatability, and enhance appetite of poultry. As well, essential oils of black seed block the effect of pathogens in the digestive system and improve feed intake, feed conversion ratio, and carcass yield (Gilani et al., 2004).

Furthermore, body weight and body gain of the studied black seed group showed significant increase (Al-Beitawi \& El-Ghousein, 2008; Radwan, 2003), and these findings confirm the fact that black seed rich in the unsaturated fatty acids such as oleic, linoleic, and leinolenic acids, which are considered essential for growth, beside nigella, thymoquinone, and thymohydoquinone, which shown to possess antimicrobial and pharmacological activities (Hassan, Askar, \& Gehan EL-shourbagy, 2004).

Black seed as a nutritional factor demonstrated a degree of protective effect under the heat stress condition, as it revealed preserved hepatic sinusoids, and the hepatic cords maintained their architecture, with no inflammatory cell infiltrations; however, less degree of hepatocytes vacuolation and veins congestion were observed. These results were associated with significant increase in total antioxidant capacity, with a significant decrease in glucose, cholesterol, and catalase levels. All of the abovementioned effects confirmed the ability of black seed to practice many therapeutic effects such as hepatoprotective (Al-Ghamdi, 2003; Kanter, Coskun, \& Budancamanak, 2005), antihistaminic, and antioxidative (Guler, Ertas, Kızıl, Dalkılıc, \& Ciftci, 2007; Kanter, Coskun, \& Uysal, 2006).

Feeding of the pigeons on propolis diet under heat stress condition leading to significant decrease in feed intake (Daneshmand, Sadeghi, \& Karimi, 2012; Silici, Karabacak, Balci, \& Cankaya, 2007) due to the characteristics of propolis that has a strict genuine odor, volatile compounds, and a bitter taste, which may cause the broilers rejecting the diet or affect negatively on their diet desire (Daneshmand et al., 2012). Moreover, feeding on propolis was previously reported to be accompanied by non-significant effect on ingestive and preening behavior (Mahmoud, Abdel-Rahmana, Darwisha, \& Applegateb, 2015), body gain (Silici et al., 2007), and feed conversion ratio (Tekeli, Kutlu, \& Celik, 2011).

Propolis diet during heat stress condition reported no protective effect on the hepatic tissues under heat stress condition, while it revealed significant increase in total antioxidant capacity, with significant decreases in catalase, glucose, and cholesterol levels (Daneshmand et al., 2012), confirming that the antioxidant activity of propolis (Banskota, Tezuka, \& Kodata, 2001; Vidda-Martos, Ruiz-Navajas, Fernández-López, \& Perez-Alvarez, 2008) contains high content of flavonoids, caffeic acid, and polyephnols (El-Damrawy, 2014).

\section{Conclusions}

It is clear that heat stress condition affected the behavior, performance, and hepatic tissue morphology, including a decline of feed intake, body weight, body gain, and total antioxidant capacity, with increased aggressive behavior, catalase, glucose, and cholesterol levels of pigeon under investigation. Hepatic tissue as well revealed damage of hepatocytes with vacuolation, venous congestion, and inflammatory cell depositions. Using water bath or feeding on feed additives such as black seed minimized these defects, and allows the birds to practice normal behavior under heat-stressed condition, and preserved hepatic architecture. 


\section{Abbreviations}

ME: Metabolized energy

\section{Acknowledgements}

The authors would like to thank the members of Animal Hygiene Department Faculty of Veterinary Medicine, Assiut University, Egypt, for their kind help and support during the experiment

\section{Availability of data and materials}

Pigeon purchased from pigeon fanciers and the kits purchased from the specific producing company. And all data are available from the corresponding author upon request.

\section{Authors' contributions}

ERD designed the experiment, performed the behavior and performance analysis, and wrote the manuscript. SRK conducted the hepatic gross examination and histological analysis and wrote the manuscript. HRI designed the diets used in the experiments. All authors reviewed and approved the manuscript.

\section{Ethics approval and consent to participate}

This study was carried out in accordance to the ethical rules for handling the experimental animals, Hygiene Department, Faculty of Veterinary Medicine, Assiut University, Egypt.

\section{Competing interests}

The authors declare that they have no competing interests.

\section{Publisher's Note}

Springer Nature remains neutral with regard to jurisdictional claims in published maps and institutional affiliations.

\section{Author details}

${ }^{1}$ Department of Animal Hygiene, Faculty of Veterinary Medicine, Assiut University, Assiut 71526, Egypt. ${ }^{2}$ Department of Anatomy and Embryology, Faculty of Veterinary Medicine, Sohag University, Sohag 82524, Egypt. ${ }^{3}$ Department of Animal Nutrition and Clinical Nutrition, Faculty of Veterinary Medicine, Assiut University, Assiut 71526, Egypt.

\section{Received: 26 December 2017 Accepted: 9 April 2018}

\section{Published online: 24 April 2018}

\section{References}

Abou Khashaba, H. A., Mariey, Y. A., \& Ibrahem, M. A. (2009). Nutritional and management studies on the pigeon: effect of selenium source and level on pigeon's performance. Egyptian Poultry Science Journal, 29(IV), 947-969.

Abou Khashaba, H. A., Mariey, Y. A., Sayed, M. A. M., \& Elgabry, H. E. (2008). Nutritional and management studies on the pigeon: estimate of protein requirements. Jounal Agriculture Scince. Mansoura Univ., 33, 8447-8461.

Aengwanich, W., \& Simaraks, S. (2004). Pathology of heart, lung, liver and kidney in broilers under chronic heat stress. Songklanakarin J. Sci. Technol, 26(3), 417-424

Agrawal, S., \& Gupta, D. (2013). Assessment of liver damage in male albino rats after repetitive heat stress of moderate level. National Journal of Physiology, Pharmacy \& Pharmacology, 3, 147-152.

Ahmed, R.R. and Kh. Mazher, (2009). Histological, histochemical and biochemical changes in the liver, kidney, lung, and spleen under the effect of repetitive hyperthermia in rat neonates. IJCP, Vol 2, No 2, Spring

Al-Azraqi, A. A. (2008). Pattern of leptin secretion and oxidative markers in heatstressed pigeons. International Journal of Poultry Science, 7, 1174-1176.

Al-Beitawi, N., \& El-Ghousein, S. S. (2008). Effect of feeding different levels of Nigella sativa seeds (black cumin) on performance, blood constituents and carcass characteristics of broiler chicks. International Journal of Poultry Science, 7, 715-721.

Al-Gamal, M. A. (2014). Blood biochemical profile of young and adult racing pigeons (Columba liviadomestica) in Egypt. Middle East Journal of Applied Sciences, 4, 528-538.

Al-Ghamdi, M.S.,(2003). Protective effect of Nigella sativa seeds against carbon tetrachloride-induced liver damage. The American Journal of Chinese Medicine. 2003;31(5):721-728
Altan, O., Şeremet, C., \& Bayraktar, H. (2013). The effects of early environmental enrichment on performance, fear and physiological responses to acute stress of broiler. Arch.Geflügelk., 77, 23-28.

Appleby, M. C., \& Hughes, B. O. (1995). The Edinburgh modified cage for laying hens. British Poultry Scince, 36, 707-718.

Bancroft, J. D., Layton, C., Suvarna, S. K. (2013). Bancroft's theory and practice of histological techniques; 7th edition. Churchill Livingstone: Elsevier. eBook ISBN: 9780702068867, eBook ISBN: 9780702068874, Hardcover ISBN: 9780702068645.

Banskota, A. H., Tezuka, Y., \& Kodata, S. (2001). Recent progress in pharmacological research of propolis. Phytotherapy Research, 15, 561-571.

Beutler, E., (1984). Red cell metabolism: a manual of biochemical methods. 3rd ed. Grune\& Stratton, INC. New York, USA

Bozakova, N. (2008). Ethological aspects of chicken's welfare under different environmental conditions during summer time. Ecology and Future Bulgarian Journal of Ecological Science, 7, 29-33.

Caliborne, A. L. (1985). Assay of catalase. In R. A. Greenwald (Ed.), Handbook of oxygen radical research. Baco-Raton: CRC Press.

Cornetto, T., \& Estevez, I. (2001). Behavior of the domestic fowl in the presence of vertical panels. Poultry Science, 80, 1455-1462.

Cornetto, T. L., \& Estevez, I. (2002). Using artificial cover to reduce aggression and disturbances in domestic fowl. Applied. Animal Behavior. Science, 75, 325-336.

Crossmon, G. A. (1937). Modification of Mallory's connective tissue stain with a discussion of the principles involved. The Anatomical Record, 69, 33-38.

Dagaas, C. T., \& Claveria, J. N. (2008). On farm performance of broilers subjected to $40 \%$ level of feed restriction on the third week of age. Philippine J. Vet. Anim. Sci., 34, 177-186.

Daneshmand, A., Sadeghi, G. H., \& Karimi, A. (2012). The effects of a combination of garlic, oyster mushroom and propolis extract in comparison to antibiotic on growth performance, some blood parameters and nutrients digestibility of male broilers. Revista Brasileira de Ciência Avícola, 14, 141-147.

Dollah, M. A., Parhizkar, S., Abdul, L. L., \& Bin Hassan, M. H. (2013). Toxicity effect of Nigella sativa on the liver function of rats. Advanced Pharmaceutical Bulletin, 3, 97-102.

Durrani, F. R., Chand, N., Zaka, K., Sultan, A., Khattak, F. M., \& Durrani, Z. (2007). Effect of different levels of feed added black seed (Nigella sativa L) on the performance of broiler chicks. Pakistan Journal Biology Science, 10, 4164-4167.

El-Damrawy, S. Z. (2014). Effect of grape seed extract on some physiological changes in broilers under heat stress. Egyptian Poultry Science Journal., 34, 333-343.

EL-Shoukary, R. D. M., Madeha, H. A., Darwish, M. A., \& Abdel-Rahman, M. (2014) Behavioral, performance, carcass traits and hormonal changes of heat stressed broilers feeding black and coriander seeds. Journal of Advanced Veterinary Research, 4, 97-101.

Ewing, S. A., Lay Jr., D. C., \& Borell, E. V. (1999). Farm animal well-being. New Jersey: Simon \& Schuster Company.

Fabricius, E., \& Jansson, A. M. (1963). Laboratory observations on the reproductive behavior of the pigeon (Columba livia) during the pre-incubation. Animal Behavior, 11, 535-554

Faisal, B. A., Abdel-Fattah, S. A., El-Hommosany, Y. M., Abdel-Gawad, N. M., \& Ali, M. F. M. (2008). Immunocompetence, hepatic heat shock protein 70 and physiological responses to feed restriction and heat stress in two body weight lines of Japanese quail. International Journal of Poultry Science, 7, 174-183.

Felver-Gant, J. N., Mack, L. A., Dennis, R. L., Eicher, S. D., \& Cheng, H. W. (2012) Genetic variations alter physiological responses following heat stress in 2 strains of laying hens. Poultry Science, 91, 1542-1551.

Flanagan SW, Ryan AJ, Gisolfi CV, PL Moseley., (1995). Tissue specific HSP70 response in animals undergoing heat stress. American Journal of Physiology.3; 268: 277.

Furlan, R. L., Macari, M., Moraes, R. D., Malheiros, E. B., \& Secato, E. R. (1999). Hematological and gasometric response of different broiler chickens strains under acute heat stress. Revista Brasileria de Ciencia avicola., 1, 77-84.

Gilani, A. H., Jabeen, Q., \& Khan, M. A. U. (2004). A review of medicinal uses and pharmacological activities of Nigella sativa. Pakistan Journal. Biology Science, 7, 441-451.

Gregory, N. G. (1998). Animal welfare and meat science. Cambridge: The University Press.

Guler, T., Ertas, O. N., Kızıl, M., Dalkılıc, B., \& Ciftci, M. (2007). Effect of dietary supplemental black cumin seeds on antioxidant activity in broilers. Medycyna Weterynaryjna, 63(9), 1060-1063.

Gwenith A. W. (1986). Development of pigeon feed for commercial souab production in British Columbia. A Thesis Of B.Sc. (Agr.). University Of 
British Columbia. https://circle.ubc.ca/bitstream/id/87341/UBC_1986_A6_ 7\%20W29 5.pdf.

Hall, DM, Oberley, TD, Moseley, PL, Buettner, GR, Oberley, LW, Weindruch, R, KC. Kregel, (2000). Caloric restriction improves thermotolerance and reduces hyperthermia induced cellular damage in old rats. FASEB Journal 14: 78-86.

Harris, H. F. (1900). On the rapid conversion of haematoxylin into haematin in staining reactions. Journal of Applied Microscopy and laboratory Methods, 3, 777-786.

Hassan, I. I., Askar, A. A., \& Gehan EL-shourbagy, A. (2004). Influence of some medicinal plants on performance, physiological and meat quality traits of broiler chicks. Egyptian Poultry Science Journal, 24, 247-266.

Kamraa, Z., Sarwar, M., Mahr, N., Nadeem, M. A., Mushtaq, T., Ahmed, T., ... Mushtaq, M. H. (2008). Effect of low levels of dietary protein on growth, protein utilisation and body composition of broiler chicks from one to twenty-six days of age. Avian Biology Research, 1, 19-25.

Kanter, M., Coskun, O., \& Budancamanak, M. (2005). Hepatoprotective effect of Nigella sativa $L$ and Urtica dioica $L$ on lipid peroxidation, antioxidant enzyme systems and liver enzymes in carbon tetrachloride-treated rats. World Journal of Gastroenterology, 11, 6684-6688.

Kanter, M., Coskun, O., \& Uysal, H. (2006). The antioxidative and antihistaminic effect of Nigella sativa and its major constituent, thymoquinone on ethanolinduced gastric mucosal damage. Archives of Toxicology, 80, 217-224.

Laudadio, V., Dambrosio, A., Normanno, G., Khan, R. U., Naz, S., Rowghani, E., \& Tufarelli, V. (2012). Effect of reducing dietary protein level on performance responses and some microbiological aspects of broiler chickens under summer environmental conditions. Avian Biology Research, 5, 88-92.

Luyckx, K., Van Coillie, E., Dewulf, J., Van Weyenberg, S., Herman, L., ZoonsE Vervaet, J., ... De Reu, K. (2017). Identification and biocide susceptibility of dominant bacteria after cleaning and disinfection of broiler houses. Poultry Science, 96, 938-949.

Mack, L. A., Felver-Gant, J. N., Dennis, R. L., \& Cheng, H. W. (2013). Genetic variation alter production and behavioral responses following heat stress in 2 strains of laying hens. Poultry. Scince., 2, 285-294.

Mahmoud U.T.; M.A. M.Abdel-Rahmana, M. H. A.Darwisha, T.J. Applegateb, H.-W. Chengc ., (2015). Behavioral changes and feathering score in heat stressed broiler chickens fed diets containing different levels of propolis. Applied Animal Behavior Science 166, 98-105

Moreki, J.C., (2006). Family poultry production, poultry today. Ministry of Agriculture, Gaborone, Botswana; 1-11.

Mujahid, A., Akiba, Y., \& Toyomizu, M. (2009). Progressive changes in the physiological responses of heat-stressed broiler chickens. Journal Poultry Science, 46, 163-167.

Murton, R. K., Thearle, R. J., \& Lofts, B. (1969). The endocrine basis of breeding behavior in the feral pigeon (columba livia) : i. effects of exogenous hormones on the pre-incubation behavior of intact males. Animal Behavior, $17,286-306$.

Natt, M. P., \& Herrick, C. A. (1952). A new blood diluent for counting erthrocytes and leucocytes of the chicken. Poultry Science, 31, 735-738 Cited by Alan M. Fudge (2001). Laboratory Medicine (avian and exotic pets) 1st edition,W.B. Saunders Company.

Ohara, A., Oyakawa, C., Yu, Y., Ninomiya, S., \& Shusuke, S. (2015). Effect of environmental enrichment on the behavior and welfare of Japanese broilers at a commercial farm. Japan Poultry Science Association, 52, 323-330.

Padmanabhan, R., NM, A. L.-M., Ahmed, I., Kataya, H. H., \& Ayoub, M. A. (2005). Histopathological, histochemical and electron microscopic change of the placenta induced by maternal exposure to hyperthermia in the rat. International Journal of Hyperthermia, 21, 29-44.

Pavlik, A., Jezova, D., Zapletal, D., Bakos, J., \& Jelinek, P. (2008). Impact of housing technology on blood plasma corticosterone levels in laying hens. Acta. Veterinary. Hung, 56, 515-527.

Pawan, K. V., Singh, Y., Raina, R., \& Kumar, J. (2012). Stress biomarkers in Vanaraja chicken maintained under various rearing systems. Journal of Advanced Veterinary Research., 2, 5-8.

Piyathaisere, D. V., Margalit, E., Chen, S. J., Shyu, J. S., D'Anna, S. A., WEILAND, J. D., et al. (2003). Heat effects on retina. Ophthalmic Surgery, Lasers \& Imaging, 34, $114-120$

Prieto, M. T., \& Campo, J. L. (2010). Effect of heat and several additives related to stress levels on fluctuating asymmetry, heterophil: lymphocyte ratio, and tonic immobility duration in white leghorn chicks. Poultry Science, 89, 2071-2077.

Radwan, Nadia L., (2003). Effect of using some medicinal plants on performance and immunity of broiler chicks. Ph.D. Thesis, Fac. of Agric.,
Cairo Uni. http://www.cu.edu.eg/thesis_pdf/1975\%20Thesis_ Effect\%20of\%20using\%20some\%20medicinal\%20plants\%20on.pdf.

Rowell, L. B., Brengelmann, G. L., Blackmon, J. R., Twiss, R. D., \& Kusumi, F. (1968). Splanchnic blood flow and metabolism in heat-stressed man. Journal of Applied Physiology, 24, 475-484.

Schalm, D. W., Jain, N. C., \& Caroll, E. J. (1975). Veterinary hematology, (3rd ed.). PA. USA: Lea and Febiger.

Silici S.; Karabacak, M.; Balci, E. and S. Cankaya., (2007). Effect of the propolis on the performance and carcass characteristics of growing quail. Mellifera 2007 Vol.7 No.13/14 pp.20-26 ref.16

Soleimani, A. F., Kasim, A., Alimon, A. R., \& Zulkifli, I. (2008). Durability of induced heat tolerance by short term heat challenge at broilers marketing age. Pakistan journal of biology sciences, 11, 2163-2166.

Spiteri, N. J. (1975). "Social especially agonistic behavior in the pigeon, Durham theses, Durham University." Available at Durham E-Theses Online: http:// etheses.dur.ac.uk/8902/

Spudeit, W. A., SarettaSulzbach, N., Bittencourt Mde, A., Duarte, A. M., Liang, H., Lino-de-Oliveira, C., \& Marino-Neto, J. (2013). The behavioral satiety sequence in pigeons (Columba livia). Description and development of a method for quantitative analysis. Physiology \& Behavior, 122, 62-71.

Suzuki, S., Hotchkiss, J. R., Takahashi, T., Olson, D., Adams, A. B., \& Marini, J. J. (2004). Effect of core body temperature on ventilator-induced lung injury. Critical Care Medicine, 32, 144-149.

Te Braake, F. W., Schierbeek, H., de Groof, K., Vermes, A., Longini, M., Buonocore, G., \& van Goudoever, J. B. (2008). Glutathione synthesis rates after amino acid administration directly after birth in preterm infants. American Journal of Clinical Nutrition, 88, 333-339.

Tekeli, A., Kutlu, R. H., \& Celik, L. (2011). Effects of Z. officinale and propolis extracts on the performance, carcass and some blood parameters of broiler chicks. Current Research Poultry Science, 1, 12-23.

Tollba, A. A. H., \& Hassan, M. S. H. (2003). Using some natural additives to improve physiological and productive performance of broiler chicks under high temperature conditions. 2-Black cumin (Nigella sativa) or garlic (Allium sativum). Egyptian Poultry Science Journal, 23, 327-340.

Vidda-Martos, M., Ruiz-Navajas, Y., Fernández-López, J., \& Perez-Alvarez, J. A. (2008). Functional properties of honey, propolis, and royal jelly. Journal of Food Science, 73, 117-123.

Yadav, S. K., Yadav, R., Aryal, B., \& Bhattacharya, S. (2012). Experimental study of effect of heat stress on rat's liver. International Journal of Pharmaceutical \& Biological Archives 2012, 3(3), 539-544.

Yang L, Tan GY, Fu YQ, Feng JH, Zhang MH., (2010). Effects of acute heat stress and subsequent stress removal on function of hepatic mitochondrial respiration, ROS production and lipid peroxidation in broiler chickens. Comparative Biochemistry and Physiology, Part C: Toxicology \& Pharmacology 2010 Mar;151(2):204-208

\section{Submit your manuscript to a SpringerOpen ${ }^{\mathcal{O}}$ journal and benefit from:}

- Convenient online submission

- Rigorous peer review

- Open access: articles freely available online

- High visibility within the field

- Retaining the copyright to your article

Submit your next manuscript at $\boldsymbol{\wedge}$ springeropen.com 